\title{
PEMBENTUKAN KARAKTER ANAK DALAM SISTEM PENDIDIKAN HINDU KUNO
}

\author{
I GEDE SUWANTANA \\ Institut Hindu Dharma Negeri Denpasar \\ gedesuwantana@gmail.com
}

\begin{abstract}
The formation of character is a discourse that continues propagated by the government of Indonesia today. This is done because the condition of the nation's degraded in many areas of life. Various types of crimes such as rape, violence, theft, fights between students, corruption, and others allegedly happened as a result of the moral degradation of the Nation. Character education is the only hope which is able to restore the values of goodness and glory of the nation. So therefore, children as the future generation should be provided with character education from the beginning.

Format of character education which is given to children, therefore, must be clear and precise objectives. Ancient Hindu educational system places great emphasis on character formation in the curriculum, so that when they are finished, besides exellence in science also grew into a wise person. Gurukula system applied that has lasted for thousands of years and is considered capable of being the foundation of both the State and society to educate and transform knowledge to the younger generation as well as capable of being a great place to shape their character.
\end{abstract}

Keywords: Character Formation, Children, Gurukula, Ancient Hindu Education

\section{Pendahuluan}

Pembentukan karakter bangsa merupakan wacana yang telah dan sedang gencar dimunculkan di tengah-tengah degradasi moral yang dialami Indonesia saat ini. Berbagai kejadian dan isu yang bertentangan dengan moralitas disinyalir sebagai akibat dari kegagalan pendidikan Indonesia. Pendidikan selama ini lebih banyak menekankan pada aspek kognitif yang membentuk kecerdasan intelek saja dan mengabaikan pendidikan karakter untuk membangun akhlak mereka. Para orang tua dewasa ini lebih tertarik mengajarkan anakanaknya calistung (membaca, menulis dan menghitung) dibandingkan tata cara berperilaku sehari-hari. Para orang tua tampak lebih bahagia melihat anaknya pandai membaca, menulis dan menghitung dibandingkan bersikap sopan, ramah, dan santun. Landasan dasar yang memungkinkan orang tua merasa dan bersikap seperti itu adalah tuntutan dari pendidikan itu sendiri, dimana saat anak-anak akan memasuki sekolah dasar, mereka dituntut untuk bisa membaca dan menulis. Sistem pendidikan dini yang ada sekarang ini terlalu berorientasi pada pengembangan otak kiri (kognitif) dan kurang memperhatikan pengembangan otak kanan (afektif, empati, dan rasa).

Kondisi tentu tidak baik dan akan berdampak pada keringnya ahklak anak-anak. Ketika tumbuh dewasa, mereka hanya memiliki kecerdasan intelek yang dominan, sedangkan kecerdasan sosial, emosi dan spiritual mereka menjadi kering. Inilah pemicu berbagai kejahatan yang berkembang sekarang, seperti perampokan, pencurian, pemerasan, korupsi, dan jenis kejahatan lainnya. Kejahatan berkembang di berbagai bidang/ segmen kehidupan, apakah di bidang politik, bisnis, pendidikan, kepolisian, dan bahkan pada institusi keagamaan. Mahatma Gandhi mengklasifikasikan jenis kejahatan tersebut 
ke dalam 'Seven Social Sins (tujuh dosa sosial)' yang diterbitkan di dalam Young India 22 Oktober 1925 (Gandhi, tt: 133-134). Adapun ketujuh hal tersebut adalah sebagai berikut:

Wealth without work (kaya tanpa kerja).

Pleasure without conscience (kesenangan tanpa kesadaran).

Education without character (pendidikan tanpa karakter). Commerce without morality (perdagangan tanpa moralitas). Science without humanity (ilmu pengetahuan tanpa kemanusiaan). Worship without sacrifice (memuja tanpa pengorbanan).

Politics without principle (politik tanpa prinsip).

Thomas Lickona (dalam Wardaya, 2015) seorang profesor pendidikan dari Cortland University - mengungkapkan bahwa ada sepuluh tanda-tanda zaman yang harus diwaspadai karena jika tanda-tanda ini sudah ada, maka itu berarti bahwa sebuah bangsa sedang menuju jurang kehancuran. Tandatanda yang dimaksud adalah:

(1) meningkatnya kekerasan di kalangan remaja,

(2) penggunaan bahasa dan kata-kata yang memburuk,

(3) pengaruh peer-group yang kuat dalam tindak kekerasan,

(4) meningkatnya perilaku merusak diri, seperti penggunaan narkoba, alkohol dan seks bebas,

(5) semakin kaburnya pedoman moral baik dan buruk,

(6) menurunnya etos kerja,

(7) semakin rendahnya rasa hormat kepada orang tua dan guru,
(8) rendahnya rasa tanggung jawab individu dan warga negara,

(9) membudayanya ketidakjujuran, dan

(10) adanya rasa saling curiga dan kebencian di antara sesama.

Melihat hal ini, para tokoh pendidikan dewasa ini melihat bahwa pendidikan karakter menjadi sangat penting diberikan di sekolah-sekolah sedini mungkin karena usia dini merupakan masa emas perkembangan (golden age) yang keberhasilannya sangat menentukan kualitas anak di masa dewasanya. Montessori menyebutnya dengan periode kepekaan (sensitive period). Pada masa ini, seluruh aspek perkembangan pada anak usia dini memasuki tahap atau periode yang sangat peka. Artinya, jika tahap ini mampu dioptimalkan dengan memberikan berbagai stimulasi yang produktif, maka perkembangan anak di masa dewasa, juga akan berlangsung secara produktif (Wardaya, 2015).

Menurut Freud kegagalan penanaman kepribadian yang baik di usia dini ini akan membentuk pribadi yang bermasalah di masa dewasanya kelak. Kesuksesan orang tua membimbing anaknya dalam mengatasi konflik kepribadian di usia dini sangat menentukan kesuksesan anak dalam kehidupan sosial di masa dewasanya kelak (Erikson, 1968). Sementara Brazelton, seorang ahli Perkembangan dan Perilaku Anak dari Amerika (dalam pendidikan karakter.com) menyebutkan bahwa pengalaman anak pada bulan dan tahun pertama kehidupannya sangat menentukan apakah anak ini akan mampu menghadapi tantangan dalam kehidupannya dan apakah ia akan menunjukkan semangat tinggi untuk belajar dan berhasil dalam pekerjaannya. 
Pada jaman Hindu Kuno, kondisi ini telah mendapat perhatian serius, sehingga sistem pendidikan yang terbentuk pada waktu itu sangat menekankan tentang pentingnya menanamkan karakter pada anak, sehingga ke depannya bisa tumbuh menjadi pribadi yang baik. Hindu Kuno menerapkan sistem pendidikan yang unik yang disebut dengan Gurukula. Sistem yang telah berlangsung berabad-abad sejak awal peradaban bangsa Arya tersebut dinyatakan sangat efektif untuk membentuk karakter anak yang sangat menentukan kepribadiannya ketika dewasa kelak.

Memang harus diakui bahwa menanamkan karakter kepada anak tidak mudah. Helen Keller menyatakan bahwa karakter tidak dapat dibentuk dengan cara mudah dan murah. Dengan mengalami ujian dan penderitaan jiwa karakter dikuatkan, visi dijernihkan, dan sukses diraih. Namun terkadang orang tua tidak bisa mengerti kondisi ini. mereka biasanya mendidik anak berdasarkan apa yang disenanginya tidak berdasarkan apa yang dibutuhkan oleh anak itu. Ada sebuah cerita menarik yang menggambarkan bagaimana orang tua biasanya mendidik anak mereka secara salah meskipun maksud mereka adalah menolong dengan penuh kasih sayang. Cerita ini diunduh dari http://www.pendidikankarakter.com, sebagai berikut:

Suatu hari seorang anak laki-laki sedang memperhatikan sebuah kepompong, ternyata di dalamnya ada kupu-kupu yang sedang berjuang untuk melepaskan diri dari dalam kepompong. Kelihatannya begitu sulitnya, kemudian si anak laki-laki tersebut merasa kasihan pada kupu-kupu itu dan berpikir cara untuk membantu si kupu-kupu agar bisa keluar dengan mudah. Akhirnya si anak lakilaki tadi menemukan ide dan segera mengambil gunting dan membantu memotong kepompong agar kupu-kupu bisa segera keluar dari sana. Alangkah senang dan leganya si anak laki laki tersebut.Tetapi apa yang terjadi? Si kupu-kupu memang bisa keluar dari sana, namun kupu-kupu tersebut tidak dapat terbang, hanya dapat merayap. Ternyata bagi seekor kupu-kupu yang sedang berjuang dari kepompongnya tersebut, yang mana pada saat dia mengerahkan seluruh tenaganya, ada suatu cairan didalam tubuhnya yang mengalir dengan kuat ke seluruh tubuhnya yang membuat sayapnya bisa mengembang sehingga ia dapat terbang, tetapi karena tidak ada lagi perjuangan tersebut maka sayapnya tidak dapat mengembang sehingga jadilah ia seekor kupu-kupu yang hanya dapat merayap.

Itu adalah potret singkat tentang pembentukan karakter, akan terasa jelas dengan memahami contoh kupu-kupu tersebut. Seringkali orangtua dan guru, lupa akan hal ini. Bisa saja mereka tidak mau repot, atau kasihan pada anak. Kadangkala Good Intention atau niat baik orang tua belum tentu menghasilkan sesuatu yang baik. Kadangkala orang tua sering membantu mereka karena kasihan atau rasa sayang, tapi sebenarnya malah membuat mereka tidak mandiri. Membuat potensi dalam dirinya tidak berkembang. Memandulkan kreativitasnya, karena orang tua tidak tega melihat mereka mengalami kesulitan, yang sebenarnya jika mereka berhasil melewatinya justru menjadi kuat dan berkarakter.

Pembentukan karakter seorang anak butuh waktu dan komitmen dari orangtua dan sekolah atau guru (jika memprioritaskan hal ini) untuk mendidik anak menjadi pribadi yang berkarakter. Butuh upaya, waktu dan cinta dari lingkungan yang merupakan tempat dia bertumbuh. Cinta disini jangan disalah artikan dengan memanjakan. Jika orang tua taat dengan proses ini maka dampaknya 
bukan ke anak saja, kepada orang tua pun berdampak positif, paling tidak karakter sabar, toleransi, mampu memahami masalah dari sudut pandang yang berbeda, disiplin dan memiliki integritas (ucapan dan tindakan sama) terpancar pada diri orang tua. Proses ini bekerja baik bagi orangtua, guru dan anak jika komitmen pada proses pembentukan karakter tersebut kuat.

Melihat hal tersebut, Sistem Pendidikan Hindu kuno pada hakikatnya didasarkan pada man making (sebagaimana yang dinyatakan dengan contoh di atas) dan tidak hanya sekedar untuk bertahan hidup. Man making (pembentukan manusia) dianggap sebagai sesuatu yang artistik dan tujuan pendidikan yang benar. Pendidikan mesti dijadikan sebagai sarana realisasi diri, sarana untuk tujuan akhir tertinggi dari kehidupan, yaitu Mukti atau Emansipasi. Sistem Pendidikan India kuno juga merupakan hasil dari Indian theory of knowledge (teori pendidikan India) sebagai bagian dari skema kehidupan dan nilai-nilai. Skema ini memperhitungkan fakta tentang kehidupan dan kematian sebagai bentuk kebenaran yang kekal. Hal ini memberikan visi tertentu tentang material dan moral, fisik dan spiritual, kepentingan dan nilai-nilai kehidupan yang fana dan permanen yang dapat didefinisikan secara jelas serta secara ketat dibedakan. Pendidikan harus membantu dalam hal pemenuhan diri ini, tidak hanya mendapatkan pengetahuan obyektif belaka. Menurut teori pendidikan India kuno, melatih pikiran dan proses berpikir itu penting untuk memperoleh pengetahuan. Siswa harus mampu mendidik dirinya sendiri dan mencapai pertumbuhan mentalnya sendiri (Indiatva, 2011).

\section{Pembahasan}

\subsection{Proses dan Tujuan Sistem Pendidikan Hindu Kuno}

Sistem Pendidikan Hindu kuno memiliki tiga proses yang sederhana, yakni Shravana, Manana dan Nididhyasana. 1) Shravana adalah mendengarkan kebenaran dari ucapan seorang guru. Pengetahuan ini secara teknis disebut sebagai Sruti (apa yang didengar oleh telinga dan tidak apa yang dilihat secara tertulis). Pengucapan menjadi sangat penting. Jika pengucapan kata berbeda, maka makna asli dari kalimat atau kata tersebut juga akan berbeda; 2) Manana, artinya siswa perlu menafsirkan sendiri makna dari pelajaran yang diberikan oleh guru sehingga mereka dapat mengasimilasi sepenuhnya. Siswa mesti merenungkan apa yang telah didengar. Cara ini merupakan sarana efektif untuk menghilangkan keraguan tentang pengetahuan yang telah diterima melalui Shravana. 3) Nididhyasana berarti pemahaman yang lengkap atas kebenaran yang diajarkan sehingga siswa dapat hidup dalam kebenaran itu dan bukan hanya sekedar menjelaskannya melalui kata-kata. Pengetahuan harus menghasilkan realisasi; merenungkan esensi dari apa yang telah secara intelektual dipahami sampai pada keyakinan total.

Dari ketiga proses tersebut diharapkan tujuan pendidikan akan tercapai. Paling sedikit ada enam tujuan dari sistem pendidikan India kuno, yakni

1. Self-control (kontrol diri)

2. Development of character (pembentukan karakter)

3. Social awareness (kesadaran sosial)

4. Integral development of personality (pengembangan kepribadian secara integral)

5. Propagation of purity (mengembangkan kemurnian)

6. Preservation of knowledge and culture (memelihara pengetahuan dan budaya) 
Pemikir Hindu kuno menyatakan bahwa pencapaian intelektual belaka merupakan konsekuensi yang paling minimal jika dibandingkan dengan pengembangan moral dan karakter. Efek menghancurkan akibat pemutusan hubungan antara kekuasaan dan kebajikan, antara kemajuan intelektual dan ilmiah dengan nilai-nilai moral dan spiritual, yang begitu jelas diilustrasikan di Barat di era modern, sangat dirasakan oleh India kuno; Oleh karena itu mereka bersikeras bahwa, saat seseorang sedang menempuh pendidikan, moralitas harus juga dikembangkan, perasaan baik terhadap manusia seharusnya diperkuat dan kekuasaan atas pikirannya harus disempurnakan, sehingga ia mampu mengikuti hati nuraninya. Namun, atmosfer di mana siswa tinggal sangat menentukan karakter mereka. Mereka berada di bawah pengawasan langsung dari guru mereka secara pribadi, yang memperhatikan tidak hanya kemajuan intelektual mereka saja, tetapi juga atas perilaku moral mereka. Karakter tersebut dibangun sebagian oleh pengaruh perintah langsung, sebagian oleh efek disiplin yang terus-menerus dan sebagian oleh penghormatan kepada pahlawan nasional, dipegang sebagai penghormatan tertinggi oleh masyarakat (Altekar, 1944: 10-12).

Hindu kuno melihat bahwa pendidikan harus dimulai pada masa kanak-kanak. Hindu menyatakan bahwa umur 5 dan 8 tahun merupakan waktu yang tepat untuk pendidikan primer dan menengah mereka. Hindu kuno menyatakan bahwa pendidikan bukanlah proses pasif atau proses satu sisi dan akan menjadi produktif ketika terjalin kerjasama dan rasa sukarela dari siswa. Mereka harus memiliki dorongan untuk memperoleh lebih banyak pengetahuan sehingga menyenangkan dalam mengajar mereka. Jika tidak ada keinginan nyata untuk belajar dan perbaikan, maka akan sia-sia membuang waktu dan tenaga selama pendidikan sementara siswa tidak tulus.

\subsection{Kurikulum Pendidikan Hindu Kuno}

Altekar (1944) melihat bahwa jaman kuno di India sangat mementingkan kebiasaan bangun pagi. Oleh karena itu, siswa diharuskan untuk bangun pagi. Hidup sederhana dan berpikir tinggi menjadi sesuatu yang diinginkan dan memakan makanan yang mahal dan pakaian yang mahal dilarang. Rutinitas sehari-hari memainkan sebagian besar dalam pembentukan kebiasaan. Rutinitas sehari-hari dengan hati-hati ditentukan dengan maksud untuk memungkinkan siswa membentuk kebiasaan yang baik dan menguasai mata pelajaran di akhir program mereka.

Dari rutinitas sehari-hari yang dilakukan oleh siswa tersebut, nilai karakter yang semestinya dapat dikembangkan menurut Megawangi (2004) adalah sebagai berikut :

1. Cinta Tuhan dan segenap ciptaanNya

2. Tanggung jawab, Kedisiplinan dan Kemandirian

3. Kejujuran

4. Hormat dan Santun

5. Dermawan, Suka menolong dan Gotong-royong/Kerjasama

6. Percaya Diri, Kreatif dan Pekerja keras

7. Kepemimpinan dan Keadilan

8. Baik dan Rendah Hati

9. Toleransi, Kedamaian dan Kesatuan

10. 4K ( kebersihan, kesehatan, kerapian dan keamanan)

Sedangkan menurut sumber dari Balitbang, Kementerian Pendidikan Nasional, bahwa ruang lingkup nilai moral dalam rangka 
pembentukan karakter yang harus dikembangkan adalah sebagai berikut:

1. Religius: Sikap dan perilaku yang patuh dalam melaksanakan ajaran agamadianutnya, toleran terhadap pelaksanaan ibadah agama lain, dan hidup rukun dengan pemeluk agama lain.

2. Jujur: Perilaku yang didasarkan pada upaya menjadikan dirinya sebagai orangselalu dapat dipercaya dalam perkataan, tindakan, dan pekerjaan.

3. Toleransi: Sikap dan tindakan yang menghargai perbedaan agama, suku, etnis, pendapat, sikap, dan tindakan orang lain yang berbeda dari dirinya.

4. Disiplin: Tindakan yang menunjukkan perilaku tertib dan patuh pada berbagai ketentuan dan peraturan.

5. Kerja Keras: Perilaku yang menunjukkan upaya sungguhsungguh dalam mengatasi berbagai hambatan belajar dan tugas, serta menyelesaikan tugas dengan sebaikbaiknya.

6. Kreatif: Berpikir dan melakukan sesuatu untuk menghasilkan cara atau hasil baru dari sesuatu yang telah dimiliki.

7. Mandiri: Sikap dan perilaku yang tidak mudah tergantung pada orang lain dalam menyelesaikan tugastugas.

8. Demokratis: Cara berfikir, bersikap, dan bertindak yang menilai sama Hak dan kewajiban dirinya dan orang lain.

9. Rasa Ingin Tahu: Sikap dan tindakan yang selalu berupaya untuk mengetahui lebih mendalam dan meluas dari sesuatuyang dipelajarinya, dilihat, dan didengar.

10. Semangat Kebangsaan: Cara berpikir, bertindak, dan berwawasan yang menempatkan kepentingan bangsa dan negara di atas kepentingan diri dan kelompoknya.

11. Cinta Tanah Air: Cara berfikir, bersikap, dan berbuat yang menunjukkankesetiaan, kepedulian, dan penghargaan yang tinggi terhadap bahasa, lingkungan fisik, sosial, budaya, ekonomi, dan politik bangsa.

12. Menghargai Prestasi: Sikap dan tindakan yang mendorong dirinya untuk menghasilkan sesuatu yang berguna bagi masyarakat, dan mengakui, serta menghormati keberhasilan orang lain.

13. Bersahabat/Komuniktif: Tindakan yang memperlihatkan rasa senang berbicara,bergaul, dan bekerja sama dengan orang lain.

14. Cinta Damai: Sikap, perkataan, dan tindakan yang menyebabkan orang lain merasa senang dan aman atas kehadiran dirinya.

15. Gemar Membaca: Kebiasaan menyediakan waktu untuk membaca berbagai bacaan yang memberikan kebajikan bagi dirinya.

16. Peduli Lingkungan: Sikap dan tindakan yang selalu berupaya mencegah kerusakan pada lingkungan alam di sekitarnya, dan mengembangkan upaya-upaya untuk memperbaiki kerusakan alam yang sudah terjadi.

17. Peduli Sosial: Sikap dan tindakan yang selalu ingin memberi bantuan pada orang lain dan masyarakat yang membutuhkan.

18. Tanggung-jawab: Sikap dan perilaku seseorang untuk melaksanakan tugas dan kewajibannya, yang seharusnya dia lakukan, terhadap diri sendiri, masyarakat, lingkungan (alam, sosial dan budaya), negara dan Tuhan Yang 
Maha Esa. (Balitbang Kemendiknas, 2010: 8)

Hindu kuno menyadari bahwa asosiasi dan imitasi memainkan peran besar dalam membentuk karakter dan meningkatkan kaliber mahasiswa. Bahkan seorang mahasiswa bodoh akan dapat meningkatkan kecerdasannya jika dia berhubungan erat dengan anak brilian dan meniru metodenya.

Sistem Gurukula, yang mengharuskan siswa tinggal dengan gurunya atau di sebuah rumah yang diakui reputasinya, adalah salah satu fitur yang paling penting dari pendidikan India kuno. Smritis merekomendasikan bahwa siswa harus mulai hidup di bawah pengawasan guru setelah Upanayana. Pengakuan akan pentingnya hubungan dan imitasi adalah salah satu alasan utama sistem Gurukula. Langsung, pribadi dan terusmenerus melakukan kontak dengan guru secara alami akan menghasilkan efek yang besar pada diri seorang sarjana selama periode dari masa kanak-kanak sampai remaja.

Keyakinan umum tentang Gurukulas adalah terletak di hutan jauh dari hiruk-pikuk kehidupan kota sebagian besar benar. Namun sebagian besar kasus, Gurukulas berada di desa-desa atau kota-kota. Ini terjadi secara alami sebab guru biasanya orang yang berrumah tangga. Perhatian diperlukan untuk mencari Gurukula di tempat terpencil atau taman dan di lingkungan suci. India kuno, karena itu sangat mementingkan keluarga dalam skema mereka pendidikan. Mereka menyatakan bahwa anak mulai menerima pengaruh yang membentuk karakter dan efisiensinya sejak awal konsepsi. Anak akan menjadi seperti apa yang lingkungan bentuk. Mengutip apa yang diungkapkan Dorothy Law Nollte dapat menjelaskan hal tersebut sebagai berikut:

Jika anak dibesarkan dengan celaan, maka ia belajar memaki

Jika anak dibesarkan dengan permusuhan, maka ia belajar berkelahi

Jika anak dibesarkan dengan cemoohan, maka ia belajar rendah diri Jika anak dibesarkan dengan penghinaan, maka ia belajar menyesali diri

Jika anak dibesarkan dengan toleransi, maka ia belajar mengendalikan diri

Jika anak dibesarkan dengan motivasi, maka ia belajar percaya diri Jika anak dibesarkan dengan kelembutan, maka ia belajar menghargai

Jika anak dibesarkan dengan rasa aman, maka ia belajar percaya

Jika anak dibesarkan dengan dukungan, maka ia belajar menghargai diri sendiri

Jika anak dibesarkan dengan kasih sayang dan persahabatan, maka ia belajar menemukan kasih dalam kehidupannya 


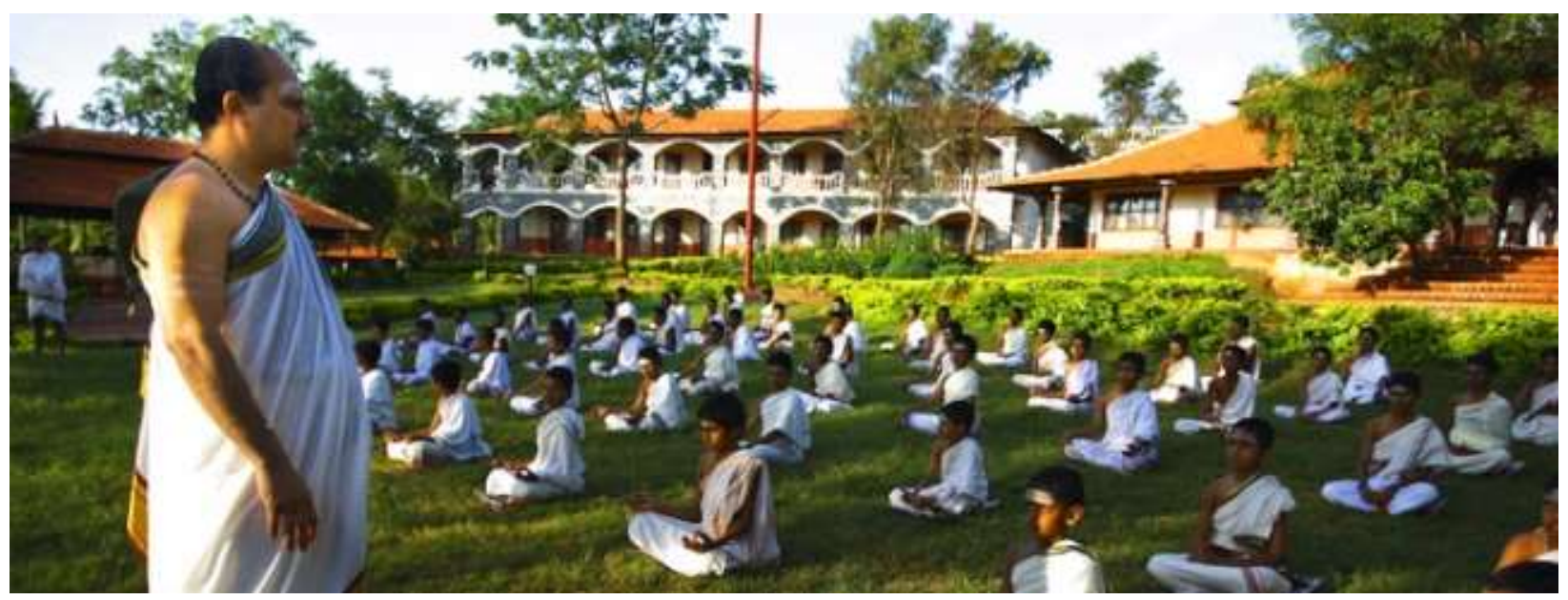

www.artofliving.org

Gambar 2.1

Model pembelajaran pendidikan Hindu Kuno

\subsection{Metode Pembelajaran}

Metode yang digunakan pada jaman Veda adalah oral, tidak dalam bentuk buku, karena buku sangat susah didapatkan. Metode ini bertahan di sekolah Veda sampai beberapa waktu terakhir. Guru biasanya mengucapkan dua kata dari bait Veda dimana siswa diminta untuk membacanya dengan intonasi dan aksen yang tepat. Jumlah kata dikurangi menjadi satu, jika ungkapan kebetulan kata gabungan. Tentu setiap siswa harus menerima perhatian secara individu di bawah sistem ini. Metode pengajaran langsung dan pribadi dan bahkan tanpa buku terjadi antara guru dan siswa. Pengulangan dan rekapitulasi merupakan bagian penting dalam rutinitas sehari-hari dari kehidupan siswa. PR yang siswa lakukan di waktu luangnya tidak latihan menulis. Ia hanya mengulang dan merekapitulasi pelajaran sudah dipelajari.

Meskipun memori dari rata-rata siswa jauh lebih baik dibandingkan sekarang, penulis dan pendidik meninggalkan cara ini untuk meringankan beban. Pendidik India kuno telah menyadari bahwa dengan sajak dapat melatih sensibilitas estetika dan memfasilitasi tugas mereka dalam menghafal. Sejak awal, debat dan diskusi selalu memainkan peran penting dalam pelatihan sastra siswa. Literatur Veda menjadi bahan yang diperdebatkan dan para pemenang akan dihormati.

Penggunaan perumpamaan sering digunakan dalam menguraikan prinsip-prinsip agar menjadi jelas, seperti yang muncul dari plot Hitopadesa dan Panchatantra, di mana prinsip-prinsip politik diajarkan dengan bercerita tentang binatang. Metode dialog diikuti oleh banyak filsuf, seperti yang akan muncul dari Upanishad dan Buddha Sastras.

Kelas-kelas di jaman India kuno biasanya kecil, terdiri dari tidak lebih dari 15 atau 20 siswa. Oleh karena itu guru dapat memberikan perhatian secara individu bagi setiap siswa. Ini merupakan salah satu poin terkuat dalam sistem pendidikan India kuno.

Agar pengawasan pribadi menjadi efektif, kerjasama dan bantuan siswa sangat 
menentukan dalam kemajuan pendidikan. Mereka harus memandu yunior di bawah pengawasan umum guru-guru mereka.

Berdasarkan pemaparan di atas maka dapat disimpulkan bahwa metode mengingat adalah yang paling utama sejak awal system pendidikan dimulai. Hal ini dilakukan karena tidak adanya ketersediaan kertas pada jaman itu dan juga tidak ada metode menulis. Kalaupun ada, menulis secara permanen akan sangat susah karena tiadanya sarana yang mendukung. Melalui metode ini setiap murid mesti mengingat setiap pelajaran dengan baik. Sehingga pada saat itu mereka memiliki seni mengingat agar mudah dan cepat. Dengan system ini murid akan mampu memahami dengan sangat baik setiap ajaran yang diberikan. Dewasa ini, karena perkembangan peralatan telah demikian canggih, metode mengingat telah kehilangan arti. Segala sesuatunya telah bisa di tulis dengan mudah tidak hanya di dalam kertas, tetapi di dalam sebuah alat elektronik.

Metode debat juga merupakan metode yang sangt efektif pada jaman itu, dimana sekarang juga mulai ditinggalkan. Pada saat itu kecerdasan seorang murid akan kelihatan dengan kemampuan debatnya. Dengan metode ini, setiap murid diharuskan untuk melakukan persiapan dengan baik sehingga bisa berdebat. Perkembangan pemikiran juga banyak muncul dari jenis perdebatan ini, sebab berbagai pertanyaan yang diajukan akan memunculkan jawaban yang bervariasi. Semakin banyak pertanyaan yang muncul, maka semakin banyak memerlukan jawaban logis dibaliknya, sehingga mahasiswa dituntut memahami secara komprehensif materi yang dipelajari.

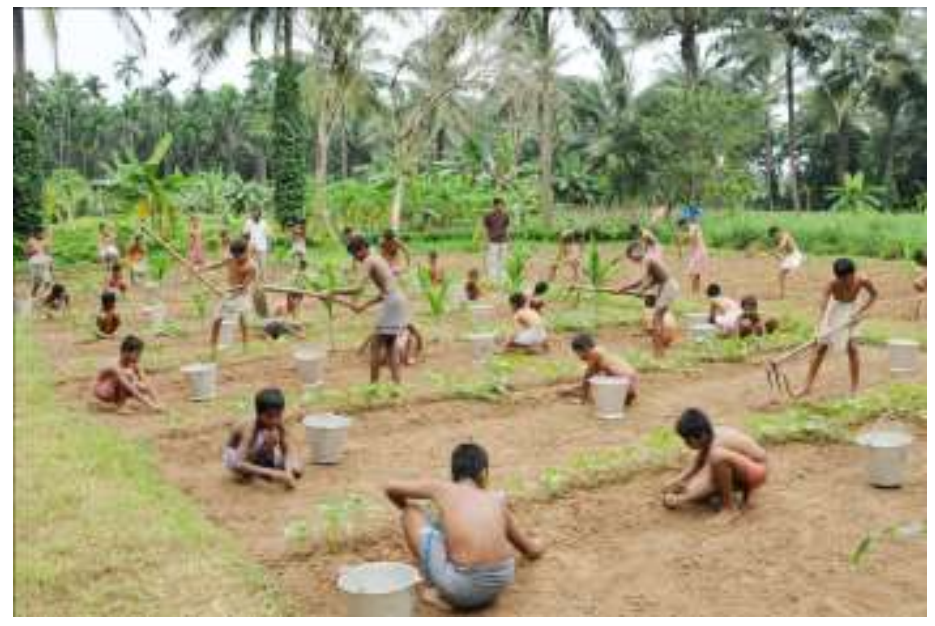

shridharmasthala.org

Gambar 2.2

Salah satu metode pembelajaran di Gurukula, sistem pendidikan Hindu Kuno

Apa yang diajarkan kepada anak-anak dalam tahap awal sekolah mereka tidak harus bagaimana cara membaca dan menulis mantra Veda (ayat), tetapi bagaimana mengucapkannya dengan benar. Selama periode ini mereka dilatih untuk menyadari perbedaan antara vokal pendek dan panjang, mempelajari jenis aksen dan menguasai aturan tentang hubungan dan perpaduan dari vokal dan konsonan. 
Ada banyak bukti yang menunjukkan bahwa seni menulis yang dilakukan oleh bangsa Arya setidaknya sejak 1000 SM, atau mungkin bisa lebih awal dari tahun tersebut. Membaca dan menulis kemudian secara bertahap mulai menjadi bagian integral dari pendidikan dasar.

Tata bahasa, filologi, aritmatika, astronomi dan metrik berkembang dengan baik dalam periode ini, dan landasan yang baik di dalamnya tidak mungkin tanpa pengetahuan tentang seni menulis. Membaca dan menulis harus dimasukkan dalam pendidikan dasar, meskipun masih ada prasangka terhadap menulis. Aritmatika dasar dan tata bahasa, fonologi dan metrik juga merupakan bagian dari kurikulum utama. Sansekerta masih menjadi bahasa lisan dan Prakrit belum berkembang. Pendidikan dasar yang dilaksanakan saat itu hanya terbatas pada menumbuhkan bahasa Sansekerta.

Pendidikan dasar menjadi penting dalam sistem pendidikan selama periode 200-800 $M$ yang diawali dengan sebuah ritual keagamaan yang disebut Aksharawikarana, yang dilakukan pada usia sekitar lima atau enam tahun. Anak laki-laki mulai study mereka dengan mempelajari huruf dasar dan gabungan dan biasanya dilakukan selama sekitar enam bulan untuk menguasainya. Kemudian sekitar satu tahun dihabiskan dalam menguasai aritmatika dasar. Selama menempuh pendidikan dasar anak laki-laki diharuskan mempelajari Sutra dari Panini dan beberapa karya gramatikal sederhana lainnya dari usia 8 sampai 11 tahun.

\section{Simpulan}

Berdasarkan uraian di atas dapat disimpulkan bahwa dalam pembabakan sejarah pendidikan Hindu Kuno, pembengunan karakter merupakan hal yang sangat ditekankan. Hasil dari pendidikan adalah karakter yang baik dan perilaku yang baik. Penaklukan atau memeangkan perang tidak serta merta menjadi pahlawan. Tidak pula belajar banyak tentang kebijaksanaan dan penguasaan terhadap wanita. Ia yang telah mampu menaklukkan indra-indranya adalah pahlawan sejati . Dia yang mampu mempraktekkan kebajikan di dalam hidupnya benar-benar merupakan orang bijak.

Kebijaksanaan terdiri dari praktek nilai-nilai moral. Pengendalian indera dan praktek kebajikan membuat seseorang berkarakter. Keunggulan moral bisa datang hanya melalui pratik nilai-nilai moral. Contoh adalah lebih baik dibandingkan ajaran. Guru dan yang diajarkan merupakan cita-cita moralitas yang dilaksanakan sepanjang hidup mereka. Praktek ini dilaksanakan di dalam sebuah gurukula dimana guru dan murid tinggal bersama selama durasi pembelajaran mereka berlangsung. Di dalam sistem Gurukula ini, peran seorang guru adalah sental dan menjadi sumber teladan dan inspirasi bagi muridnya. Pembentukan karakter pada anak sangat ditentukan dari interaksi antara guru dan murid selama proses pembelajaran tersebut berlangsung.

Dalam sistem ini anak-anak tidak dipaksakan untuk langsung bisa membaca dan menulis. Hal yang paling dasar yang diberikan adalah permainan-permainan melalui anekdok-anekdok atau cerita-cerita. Demikian juga anak-anak diajarkan untuk bersentuhan langsung dengan alam. Anakanak diajak mengenal alam dengan mengajak mereka ikut menanam pohon, main di alam bebas dan diajak untuk mengenal tumbuh-tumbuhan dan hewan, sehingga diharapkan anak akan memiliki kepekaan terhadap alam. Disamping itu anak-anak juga mulai diajarkan aritmatika 
dasar dan yang sejenisnya dengan cara bermain-main sehingga anak tertarik untuk mempelajarinya.

Berdasarkan uraian tersebut, maka pendidikan di Indonesia mestinya melihat kembali warisan nenek moyang berupa system pendidikan kuno yang dalam perjalanan sejarah telah berlangsung ribuan tahun dan mampu mengantarkan anak didiknya mantap menjalani kehidupannya kelak. Penekanan pada pendidikan karakter pada sistem tersebut dianggap mampu menjaga citra pendidikan di mata masyarakat dan Negara sehingga masyarakat bisa menggantungkan harapannya kepada sistem pendidikan untuk membentuk karakter anak-anaknya untuk menjadi anak yang cerdas dan bijaksana.

\section{Daftar Pustaka}

Altekar, A.S. 1944. Education in Ancient India. Benares: Nand Kishore and Bros.

Balitbang, Departemen Pendidikan Nasional, III. 2010. Jakarta.
Erikson, E.H. 1968. Identity: Youth and Crisis. NewYork: Norton.

Gandhi, Mahatma. tt. The Collected Works of Mahatma Gandhi (electronic edition), Vol. 33.

Indiatva, 2011. Ancient Education System in India. Dalam: http://www.indiatva.com. Diakses: 25-02-2016.

Megawangi, Ratna. (2004). Pengembangan Program Pendidikan Karakter di Sekolah. Makalah. IHF,JKT .

Pendidikan Karakter, tt. Proses Pembentukan Karakter pada Anak. Dalam: http://www.pendidikankarakter.com.

Diunduh: 26-02-2016

Pendidikan Karakter. tt. Membangun Karakter Sejak Pendidikan Anak Usia Dini. Dalam: $\quad$ www.pendidikankarater.com. Diunduh: 26-02-2016.

Wardaya, Cep Unang. 2015. Pengembangan Pendidikan Karakter Anak Usia Dini dalam Keluara. Dalam http://www.tkplb.org. Diunduh: 23-02-2016. 